\title{
National Emissions Standards for Hazardous Air Pollutants Application for Approval of Construction SP-100 Ground Engineering System Test Site
}

\section{O NOI BACROFLLM} COVER

United States Department of Energy Richland, Washington 


\section{DISCLAIMER}

This report was prepared as an account of work sponsored by an agency of the United States Government. Neither the United States Government nor any agency Thereof, nor any of their employees, makes any warranty, express or implied, or assumes any legal liability or responsibility for the accuracy, completeness, or usefulness of any information, apparatus, product, or process disclosed, or represents that its use would not infringe privately owned rights. Reference herein to any specific commercial product, process, or service by trade name, trademark, manufacturer, or otherwise does not necessarily constitute or imply its endorsement, recommendation, or favoring by the United States Government or any agency thereof. The views and opinions of authors expressed herein do not necessarily state or reflect those of the United States Government or any agency thereof. 


\section{DISCLAIMER}

Portions of this document may be illegible in electronic image products. Images are produced from the best available original document. 



\section{DISCLAIMER}

This report was prepared as an account of work sponsored by an agency of the United States Government. Neither the United States Government nor any agency thereof, nor any of their employees, makes any warranty, express or implied, or assumes any legal liability or responsibility for the accuracy, compieteness, or usefulness of any information, apparatus, product, or process disclosed, or represents that its use would not infringe privately owned rights. Reference herein to any specific commercial product, process, or service by trade name, trademark, manufacturer, or otherwise does not necessarily constitute or imply its endorsement, recommendation, or favoring by the United States Government or any agency thereof. The views and opinions of authors expressed herein do not necessarily state or reflect those of the United States Government or any agency thereof. 


\section{National Emissions Standards for Hazardous Air Pollutants Application for Approval of Construction SP-100 Ground Engineering System Test Site}

Date Published

April 1990 
DOE/RL-90-15

This page intentionally left blank.

"A9I NOT MUI,'RIFFII!

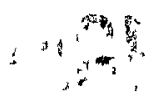


DOE/RL $-90-15$

\section{CONTENTS}

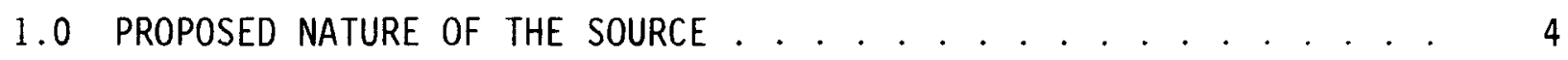

2.0 PROPOSED SIZE OF THE SOURCE ...................... 4

3.0 PROPOSED DESIGN OF THE SOURCE .................. . . . 4

4.0 OPERATING DESIGN CAPACITY . . . . . . . . . . . . . . . . . . 8

5.0 METHOD OF OPERATION ...................... 8

6.0 EMISSIONS CONTROL SYSTEM .................. . . . . . . 14

6.1 ACTIVATED REACTOR COVER GAS . . . . . . . . . . . . . . . . . 15

6.2 TRITIUM GENERATED WITHIN THE PHTS . . . . . 15

6.3 ACTIVATED REACTOR/PUMP GALLERY/TEST ASSEMBLY CELL GAS . . . . 16

6.4 EMISSIONS RELEASE RATES ................ . . . . 18

6.5 OFFSITE DOSES . . . . . . . . . . . . . . . . . . 21

7.0 REFERENCES . . . . . . . . . . . . . . . . . . . . . . . . . . . 23

APPENDIX:

A. Derived Concentration Guide .............. A-1 


\section{LIST OF FIGURES}

1 Location of the Hanford Site. . . . . . . . . . . . . . 2

2300 Area Details................. . . 3

3 Ground Engineering Test Reactor Facility in the 309 Building. . . . 5

4 SP-100 Nuclear Test Assembly in Vacuum Vessel . . . . . . . . . 6

5 SP-100 Ground Engineering Nuclear Test Assembly and Support System. 7

6 Core Map for the Nuclear Test Assembly. . . . . . . . . . . . . . . 9

7 Flow Diagram for the Primary Heat Transport System. . . . . . . . 12

8 Flow Diagram for the Secondary Heat Transport System. . . . . . . 13

9 Reactor, Pump Gallery, and Test Assembly Cells. . . . . . . . . . . 17

\section{LIST OF TABLES}

1 Controlled Emission Rates of Tritium, Argon, and Carbon . . . . . . . . . . . . . . . .

2 Offsite Dose Estimates for an Individual Receiving

Maximum Exposure to Airborne Radiological

Emissions From SP-100 (mrem/yr) . . . . . . . . . . . . 
$\mathrm{DOE} / \mathrm{RL}-90-15$

\section{NATIONAL EMISSIONS STANDARDS FOR HAZARDOUS AIR POLLUTANTS APPLICATION FOR APPROVAL OF CONSTRUCTION SP-100 GROUND ENGINEERING SYSTEM TEST SITE}

\section{INTRODUCTION}

The following Application For Approval of Construction is being submitted by the U.S. Department of Energy-Richland Operations Office (P.0. Box 550, Richland, Washington, 99352), pursuant to 40 CFR 61.07, "Application for approval of construction or modification," for the SP-100 Ground Engineering System (GES) Test Site, which will provide a new source of radioactive emissions to the atmosphere. The SP-100 GES will be located in the 309 Building of the 300 Area, as shown in Figure 2. The 300 Area is located within the boundary of the Hanford Site, as shown in Figure 1.

The U.S. Department of Energy (DOE), the National Aeronautics and Space Administration (NASA), and the U.S. Department of Defense (DOD) have entered into an agreement to jointly develop space nuclear reactor power system technology. The DOE has primary responsibility for developing and ground testing the nuclear subsystem. A ground test of a reactor is necessary to demonstrate technology readiness of this major subsystem before proceeding with the flight system development and demonstration.

As part of this program, it is proposed that the SP-100 test reactor be tested in the existing decommissioned Plutonium Recycle Test Reactor (PRTR) containment building ( 309 Building). The reactor will be operated for at least three months and up to $2 \mathrm{yr}$. Following the test, the 309 Building will be decontaminated for potential use in other programs.

It is projected that this new source of emissions will contribute approximately $0.05 \mathrm{mrem} / \mathrm{yr}$ dose (see Section 6.5 of the permit application) to the maximally exposed offsite individual. This projected dose is approximately $0.5 \%$ of the 40 CFR 61.92 regulatory limit of $10 \mathrm{mrem}$ (Section 6.5 of the permit application). This application is being submitted in response to those projected emissions that would provide the described offsite dose. 
Figure 1. Location of the Hanford Site.



39002096.6 
Figure 2. 300 Area Details.

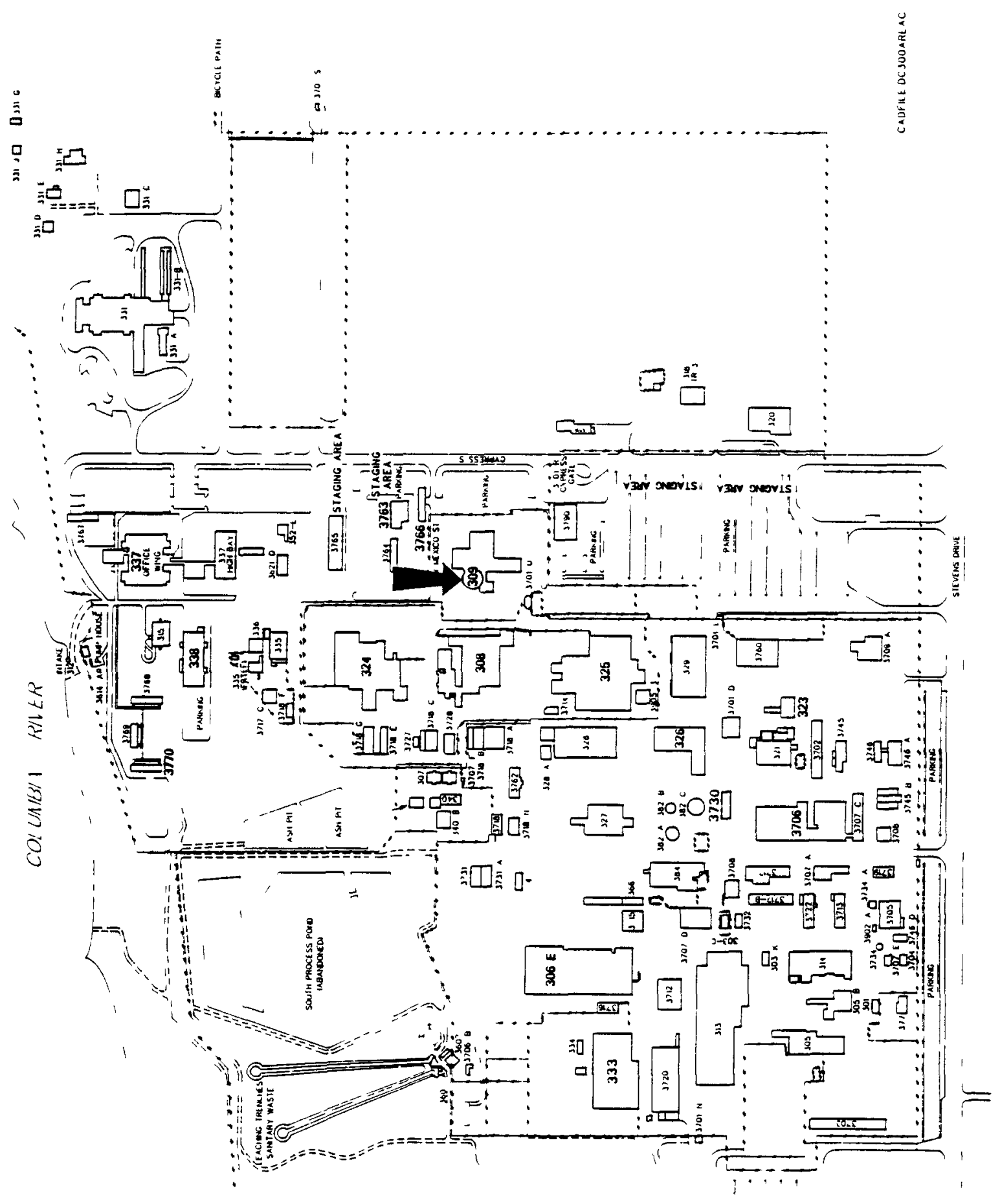


$\mathrm{DOE} / \mathrm{RL}-90-15$

\section{NATIONAL EMISSIONS STANDARDS FOR HAZARDOUS AIR POLLUTANTS APPLICATION FOR APPROVAL TO CONSTRUCT SP-100 GROUND ENGINEERING SYSTEM TEST SITE}

\subsection{PROPOSED NATURE OF THE SOURCE}

The SP-100 GES Test Site will provide a location for the operation and testing of a space-based, liquid metal-cooled, fast flux nuclear reactor in an environment closely simulating the vacuum and temperature conditions of space operations. The purpose of the SP-100 GES is to develop safe, compact, light-weight and durable space reactor power system technology. This technology will be used to provide electric power, in the range of tens to hundreds of kilowatts, to a variety of potential future civilian and military space missions requiring long-term, high-power level sources of energy.

\subsection{PROPOSED SIZE OF THE SOURCE}

The 309 Building consists of two main sections: the containment vessel (with belowgrade cells) and the services, utilities, and offices sections (see figure 3). The containment vessel will house the SP-100 GES reactor.

The containment vessel is an all-welded steel cylinder, $24.2 \mathrm{~m}(79.4 \mathrm{ft})$ in diameter, with a hemispherical dome and a hemiellipsoidal bottom. It is $31 \mathrm{~m}(102 \mathrm{ft}) \mathrm{tal1}$, extending $22.5 \mathrm{~m}(73.8 \mathrm{ft})$ above grade.

The fueled region of the reactor core, the source of neutron activation, is $41.5 \mathrm{~cm}$ (16.3 in.) high. The effective core diameter is $32.5 \mathrm{~cm}$ (12.8 in.). The reactor vessel outside diameter is $35.7 \mathrm{~cm}(14.1 \mathrm{in.})$. The fuel pellet diameter is $0.648 \mathrm{~cm}(0.26 \mathrm{in.})$, and the pin diameter is $0.775 \mathrm{~cm}$ (0.31 in.).

\subsection{PROPOSED DESIGN OF THE SOURCE}

The SP-100 GES, as described in this section, will be prototypic of the technology required for orbiting space subsystems. Figure 4 depicts the nuclear assembly. Figure 5 is a simplified diagram of the SP-100 nuclear test assembiy and support systems.

The reactor is a fast-neutron-spectrum design with sealed uranium nitride (UN) fuel pins contained in a single vessel with liquid lithium circulated 


\section{Reactor Hall}





HEDL 8603-140.1 
Figure 4. SP-100 Nuclear Test Assembly in Vacuum Vessel.






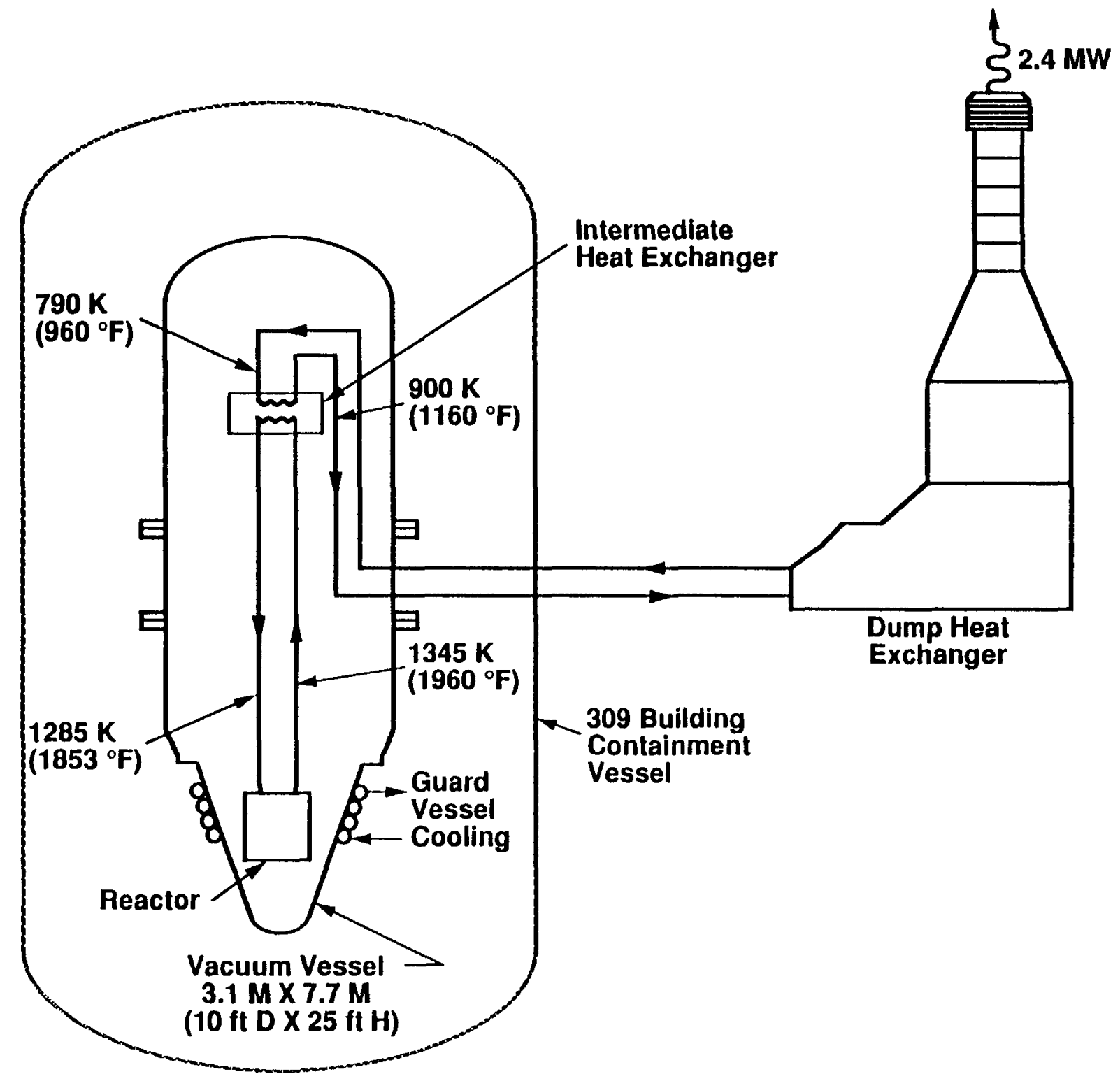

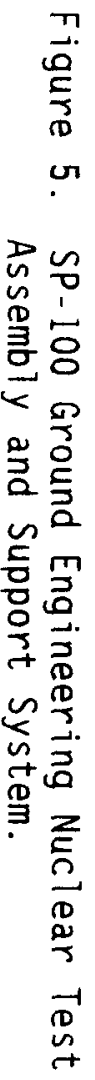


as the coolant. The reactor core is about $35 \mathrm{~cm}(13.6 \mathrm{in.})$ in diameter by $40 \mathrm{~cm}$ ( $15.5 \mathrm{in.})$ high. Niobium-1\%zirconium ( $\mathrm{Nb}-1 \mathrm{Zr}$ ) refractory metal is used for the reactor fuel cladding and structural material. The reactor is nominally rated at $2.4 \mathrm{MWt}$ and delivers its thermal energy to liquid lithium at $1961{ }^{\circ} \mathrm{F}$. The core structure is a honeycomb array of 24 hexagonal ducts, each containing up to 37 fuel pins (Figure 6). One or two locations in each duct do not contain a fuel pin but are bayonet tubes connected to an auxiliary cooling system (ACS) for decay heat removal.

Seven of the ducts in the core honeycomb structure contain hexagonal thimbles with a cylindrical cavity. Six of the thimbles receive the in-core safety rod boron carbide absorber elements. The central thimble contains the neutron source and instrumentation to measure core temperatures. The reactor is controlled by 12 hinged, radial reflector elements of beryllium oxide located outside the reactor vessel. The safety rod and control reflector systems are independent. Each provides sufficient negative reactivity during reactor assembly and adequate control and shutdown during reactor operation.

\subsection{OPERATING DESIGN CAPACITY}

It is projected that up to 2 yr may be required to validate the performance of the SP-100 GES nuclear assembly. During this test period, the SP-100 GES reactor will undergo testing while "down" (no fuel being irradiated) and while being operated at various power levels for varying lengths of time. Under current scheduling, the longest uninterrupted period of time the reactor will be operated at full power is 60 days. During this 60-day test period, the reactor will be in operation $24 \mathrm{~h}$ a day. Total full-power-level operations are projected to require approximately three months during the 2-yr period.

While the reactor is being operated, heat will be generated and that heat will be discharged to the atmosphere. At full power the reactor will discharge approximately 2.4 MWt to the atmosphere.

\subsection{METHOD OF OPERATION}

The SP-100 GES reactor, controls, and prototypic flight shield will be tested to demonstrate the integrated nuclear subsystem performance and interface compatibility. Reactor operation will occur within a vacuum vessel whose wall temperature will be $77^{\circ} \mathrm{C}\left(170^{\circ} \mathrm{F}\right)$ next to the flight shield and reactor vessel to approximate radiant heat losses from the reactor and shield encountered in space. The vacuum system will operate at about $10^{-5}$ torr to simulate a space environment and avoid oxidation of the refractory metal components of the primary heat transport system (PHTS). The following describes the primary reactor systems. 







\section{Vacuum Vesse1}

The SP-100 GES reactor, the flight shield, the lower and upper facility shields, and the PHTS will be housed in a vacuum vessel (Figure 4). The vacuum vessel will be a segmented right circular cylinder about $3.0 \mathrm{~m}$ (10 ft) in diameter with an overall length of $7.6 \mathrm{~m}(25 \mathrm{ft})$. The vacuum vessel will be fabricated from stainless steel in accordance with the American Society of Mechanical Engineers (ASME) Boiler and Pressure Vessel Code. The vacuum vessel will be supported with an interfacing structure to the containment building test cell concrete structures. The vessel will form a vacuum boundary that will allow evacuation to a high vacuum level. This vacuum level not only simulates space environment but also precludes the reaction of atmospheric and other gases with the refractory materials of the test assembly. The vacuum vessel will also be temperature controlled to provide a heat sink for radiative heat rejection from the test assembly.

\section{Vacuum System}

The SP-100 GES vacuum system will achieve the high vacuum level inside the vacuum vessel by a two-stage pumping system. The rough vacuum pumping package consists of mechanical pumps, which will reduce system pressure from one atmosphere (760 torr) down to $10^{-1}$ torr. The roughing package also contains cryostats to prevent oil back-streaming from the pumps to the vacuum vessel. The roughing package can be isolated from the vacuum vessel by separate isolation valves. The next pumping stage, rough-to-high vacuum, is achieved by a combination of turbomolecular and cryopumps. The cryopumps provide the turbopumps with additional pumping capacity. This pumping package will reduce the vacuum vessel pressure from $10^{-1}$ torr to $10^{-5}$ torr. The turbomolecular and cryopumps are connected to the vacuum vessel and are individually isolated by vacuum valves.

\section{Containment Structure}

The existing containment vessel is an all-steel cylindrical vessel $24.4 \mathrm{~m}(80 \mathrm{ft})$ in diameter and $36.9 \mathrm{~m}$ (121 ft) high, extending $22.9 \mathrm{~m}$ (75 ft) above grade. The containment vessel was designed, constructed, and tested in conformance with the ASME Boiler and Pressure Vessel Code, Section VIII, Division 1. The bottom of the vessel is $14 \mathrm{~m}(46 \mathrm{ft})$ below grade and is supported on a reinforced concrete pad. The internal design pressure of the vessel is $15 \mathrm{lbf} / \mathrm{in}^{2}$ (gage), and the design maximum external pressure is $0.501 \mathrm{bf} / \mathrm{in}^{2}$ (gage).

The containment vessel above the main operating floor is protected from internal missiles by a $0.3-\mathrm{m}-(1-\mathrm{ft}-)$ thick concrete cylindrical wall that extends approximate 1 y $10 \mathrm{~m}(33 \mathrm{ft})$ above grade. This structure also supports the rails for the overhead crane.

A 5,000 $\mathrm{ft}^{3} / \mathrm{min}$ supply unit, complete with heating coils and filters, provides general heating and ventilation to the containment area. The heating and ventilation exhaust fan is housed in the exhaust fan pit which exhausts to the 100-ft stack east of the fan pit. Two stages of high-efficiency particulate air (HEPA) filters are available before exhausting. Because no 
routine releases of radioactive particles are anticipated, the HEPA filters are provided as a precaution should an unplanned event occur that could result in the generation of radioactive particles. In addition, containment isolation valves are provided in the HVAC system to limit radioactive releases in the unlikely event of an accident.

\section{Primary Heat Transport System}

The PHTS (Figure 7) transfers the thermal energy generated in the reactor to the secondary heat transport system (SHTS). The PHTS consists of a single lithium loop that connects to the outlet plenum of the reactor. The lithium flows through multiple heat-transport pipes to a ring header, to an expansion tank, through an electromagnetic (EM) pump, through the tube side of an intermediate heat exchanger (IHX), to an electrical heater, and finally to the inlet piping of the reactor.

The expansion tank is basically a tank with the inlet and outlet pipes connected to the bottom. As the lithium heats and cools, it expands and contracts. The vapor space in the expansion tank contains a gas which contracts as the lithium expands and expands as the lithium contracts. This gas, which is called the cover gas, enables the lithium to expand and contract without causing large swings in the pressure of the system.

The electric heater is used to provide heat input for hot functional testing and isothermat physics testing without reactor heating.

The PHTS loop is located completely inside the vacuum vessel, though the EM pump stator is located external to the vacuum vessel. The EM pump stator is in a thimble that forms an extension of the vacuum vessel. The thimble maintains a vacuum environment for the pump duct.

The nominal reactor inlet temperature is $1061{ }^{\circ} \mathrm{C}\left(1861{ }^{\circ} \mathrm{F}\right)$ with a nominal outlet temperature of $1072{ }^{\circ} \mathrm{C}\left(1961^{\circ} \mathrm{F}\right)$.

\section{Secondary Heat Transport System}

The SHTS (Figure 8 ) provides for the operational rejection of the reactor heat to ambient air using sodium as the heat transfer coolant. The reactor heat is transferred from the PHTS into the stainless steel SHTS through the IHX located inside the vacuum vessel. Heat is rejected to the atmosphere by a sodium-to-air dump heat exchanger (DHX).

The SHTS loop consists of the shell side of the IHX, two EM pumps, a flow meter, miscellaneous valves and connecting pipes, and a forced-air DHX. Expansion and contraction of the sodium over the operating temperature range is accommodated by an expansion tank with an argon cover gas system. This expansion tank is similar in design to that used in the PHTS and is located outside the vacuum vessel in the DHX structure. 


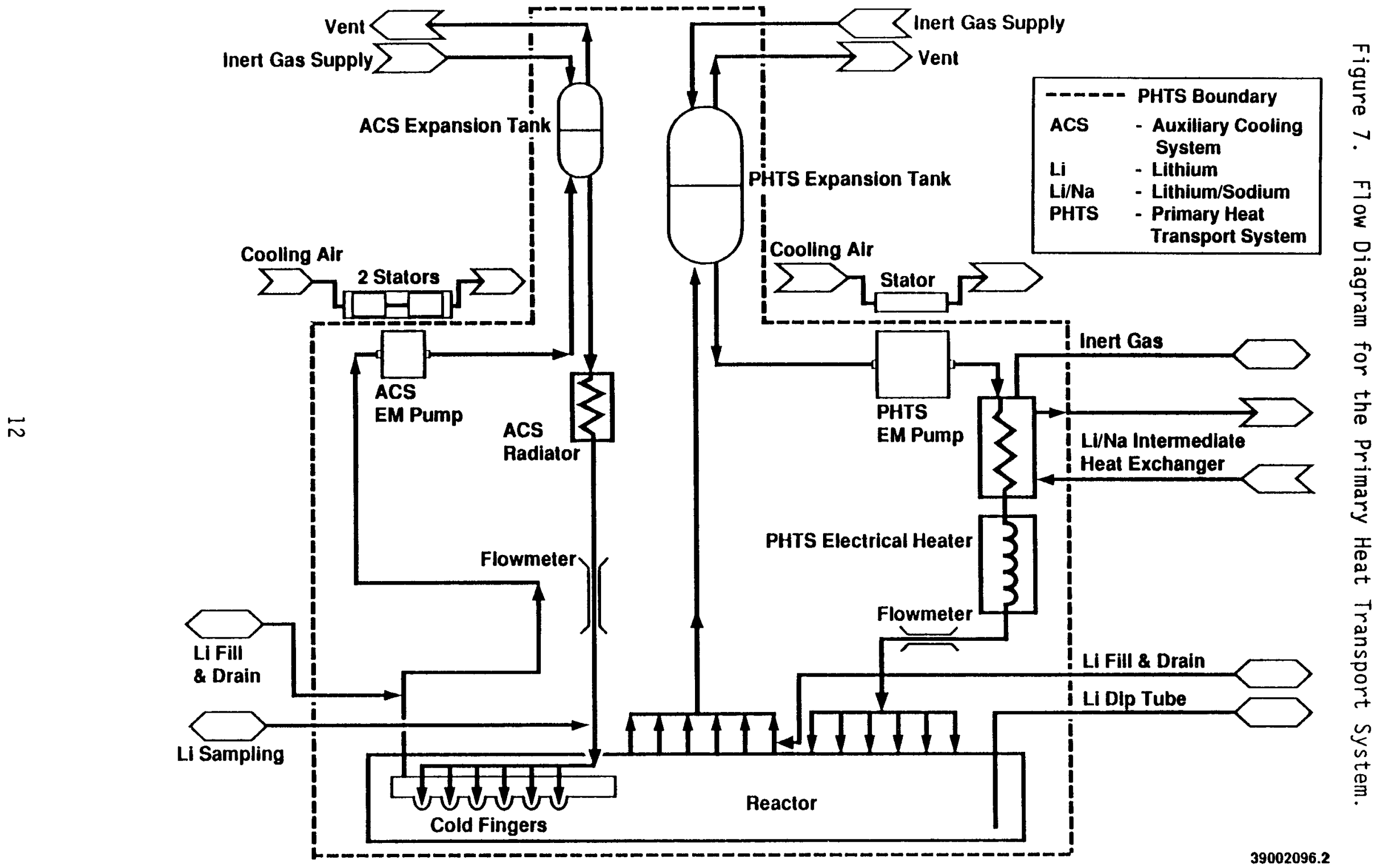






年 


\section{Auxiliary Cooling System}

The ACS provides an independent, redundant decay-heat removal path for the test reactor in the unlikely event of an off-normal occurrence that seriously impairs the ability of the PHTS to transfer reactor heat to the ultimate heat sink (e.g., failure of the PHTS boundary, failure of the SHTS boundary, or failure of the $\mathrm{DHX})$. The core incorporates 42 bayonetconfigured, heat-absorbing tubes interspersed among the fuel pins. These in-core bayonet tubes are connected to an auxiliary coolant loop with lithium as the cooling medium. The auxiliary cooling loop transports decay heat by forced circulation to a radiator panel inside the vacuum vessel. The profile of the ACS components also promotes natural convective flow in the loop. The panel radiates decay heat to the cooled vacuum vessel wall.

The secondary ACS (SACS), located outside the vacuum vessel, transports the decay heat from the vacuum vessel wall to the ultimate heat sink. The path is independent of the main coolant loop and capable of abundant cooling.

\section{Vacuum Vessel Cooling Systems}

The vacuum vessel has three sections that require demineralized water cooling to simulate typical heat losses in a space environment and to fulfill their safety-related functions. The guard vessel section is cooled by the guard vessel cooling system (GVCS). The guard vessel requires cooling to remove sensible heat should the guard vessel be retaining lithium from a PHTS leak below the flight shield and radiative heat under normal conditions. The GVCS will also serve a conditional residual heat removal function if it is retaining the primary lithium leak and keeping the core submerged in lithium. The middle section of the vacuum vessel requires cooling to remove radiant heat from the PHTS and the flight shield and to maintain the required test environment. The top hemisphere of the vacuum vessel requires cooling to remove heat from the ACS radiator panel. The SACS will transfer the heat from the top of the vacuum vessel to a heat exchanger in containment.

\subsection{EMISSIONS CONTROL SYSTEM}

Three potential sources of radioactive gaseous emissions have been identified: (1) activated reactor cover gas; (2) tritium $\left({ }^{3} \mathrm{H}\right)$ generated by neutron reaction with the lithium in the PHTS; (3) the activated reactor/ pump gallery/test assembly cell gas generated by neutron reaction with gas surrounding the lower vacuum vessel. (Fission gases will also be generated; however, they will be generated and retained within the fuel pin cladding. Routine releases, then, of fission gases, except tritium, are precluded by design and therefore are not considered in this analysis.) 


\subsection{ACTIVATED REACTOR COVER GAS}

The expansion tanks for the PHTS and the ACS are located within the vacuum vessel. Therefore, the cover gas within these tanks will receive low amounts of exposure and can be activated depending on the cover gas utilized. However, the SP-100 GES reactor PHTS and ACS are designed to operate as sealed systems and will be opened only for sampling and at the end of the test period. Thus, there is no feed/bleed of reactor PHTS and ACS cover gas during operation.

At the end of the test period, the reactor will be kept inactive for six months before disassembly. At the end of this six-month radioactivity decay period, the cover gas will be sampled. If the sample indicates that cover gas radioactivity exceeds release limits (Appendix B), the gas will be pumped into a shielded tank for additional decay time. When the sample indicates that the cover gas activity is within release limits, it will be discharged through the monitored containment exhaust plenum. Thus, no routine emissions from the reactor cover gas are expected.

\subsection{TRITIUM GENERATED WITHIN THE PHTS}

Tritium will be produced as the result of neutron bombardment of the lithium-6 $\left({ }^{6} \mathrm{Li}\right)$ in the lithium coolant. This tritium will pass through the walls of the pipes in the PHTS and ACS and will be pumped by a turbomolecular pump, monitored, and discharged up the stack. Tritium will also be generated within the reflector panels and the safety rods of the reactor. This tritium will pass from these components into the vacuum vessel and will also be pumped by a turbomolecular pump, monitored, and discharged up the stack.

Another source of tritium release will result from cleaning the core following reactor operation. Nitrogen is used to convert lithium in the PHTS and ACS into 1ithium nitride. After the nitriding process, the residue, which is in the form of solid lithium nitride, will then be removed with a water/acid flush of the coolant system. Any tritium which is dissolved in the lithium will not react with the nitrogen and will therefore be discharged up the stack, within release limits.

\subsubsection{Emission Control for Tritium Generated Within the PHTS}

Releases of tritium from the reactor will be controlled by the use of lithium enriched in ${ }^{7} \mathrm{Li}$. Naturally-occurring 1 ithium comprises of two isotopes $\left(7.5 \%{ }^{6} \mathrm{Li}\right.$ and $\left.92.5 \%{ }^{7} \mathrm{Li}\right)$. The isotope ${ }^{6} \mathrm{Li}$ absorbs a neutron and decays to yield nonradioactive helium and radioactive tritium gases. The isotope ${ }^{7} \mathrm{Li}$ will provide two nonradioactive helium atoms as a result of neutron absorption. Therefore, lithium enriched with ${ }^{7} \mathrm{Li}$ (to $99.9 \%$ with less than $0.1 \%{ }^{6} \mathrm{Li}$ ) has been selected as the coolant and the tritium control mechanism. Lithium of this enrichment reduces radioactive tritium production by a factor of 75 . 
$\mathrm{DOE} / \mathrm{RL} \cdot 90 \quad 15$

\subsection{ACTIVATED REACTOR/PUMP GALLERY/TEST ASSEMBLY CELL GAS}

The reactor cell is located between the bottom half of the vacuum vessel and the floor of the containment building (see Figure 9). The test assembly cell is located above and around the upper portion of the vacuum vessel. Between the test assembly cell and the reactor cell and around the vacuum vessel is the pump gallery cel1. Some of the neutrons produced when the reactor is operating pass through the vacuum vessel and into the reactor ce 11, the pump gallery cell, and the test assembly cell. Gaseous activation products may be formed when the neutrons interact with the cell gas. The activation products formed depend on the type of gas utilized as the cell gas. This gas is held in the reactor cell, the pump gallery cell, and the test assembly cell. Any release from these cells is from seal leakage and is to containment. The leakage is carried, in turn, by ducting to the stack, monitored, and exhausted to the atmosphere.

\subsubsection{Emission Controls for Activated Reactor/Pump Gallery/Test Assembly Cell Gas}

The SP-100 GES utilizes a sealed cell gas system to control radioactive emissions. By utilizing a sealed cell gas system, the cell gas can be held for a relatively long period of time to allow the activation products to decay to stable atoms once the reactor is shut down and the neutron source which causes activation is eliminated. This will provide a hold-up time much greater than can be provided by either reducing the flow rate of the exhaust gas while the reactor is operating or by increasing the volume of exhaust ducting. It should be noted, however, that the use of a sealed system will not totally eliminate radioactive emissions from the cell gas system while the reactor is operating.

Radioactive emissions are the result of leakage from the three cells into the containment area around the cells resulting from numerous penetrations (openings for pipes, instrumentation, access) into the cells. (The cover gas system is not expected to leak because it is a completely isolated system.) Special precautions will be taken and design features will be developed to limit the leak rate to less than $310 \mathrm{~cm}^{3} / \mathrm{s}$ from the pump gallery and the test assembly cells. These precautions include the following actions:

- The test assembly cell and the pump gallery cell will be provided with a high-integrity liner (welded steel-lined construction), a high-integrity seal design, and welded penetrations.

- The reactor cell will be provided with a high-integrity liner (welded steel-lined construction), welded flexible seal, and high integrity penetrations.

The leakage rate from the reactor cell is not critical because of the slow activation rate of the nitrogen cell gas. In the event that leakage occurs, the net mass flow rate will be out of the cells and into the containment building because the cells will be maintained at a positive 


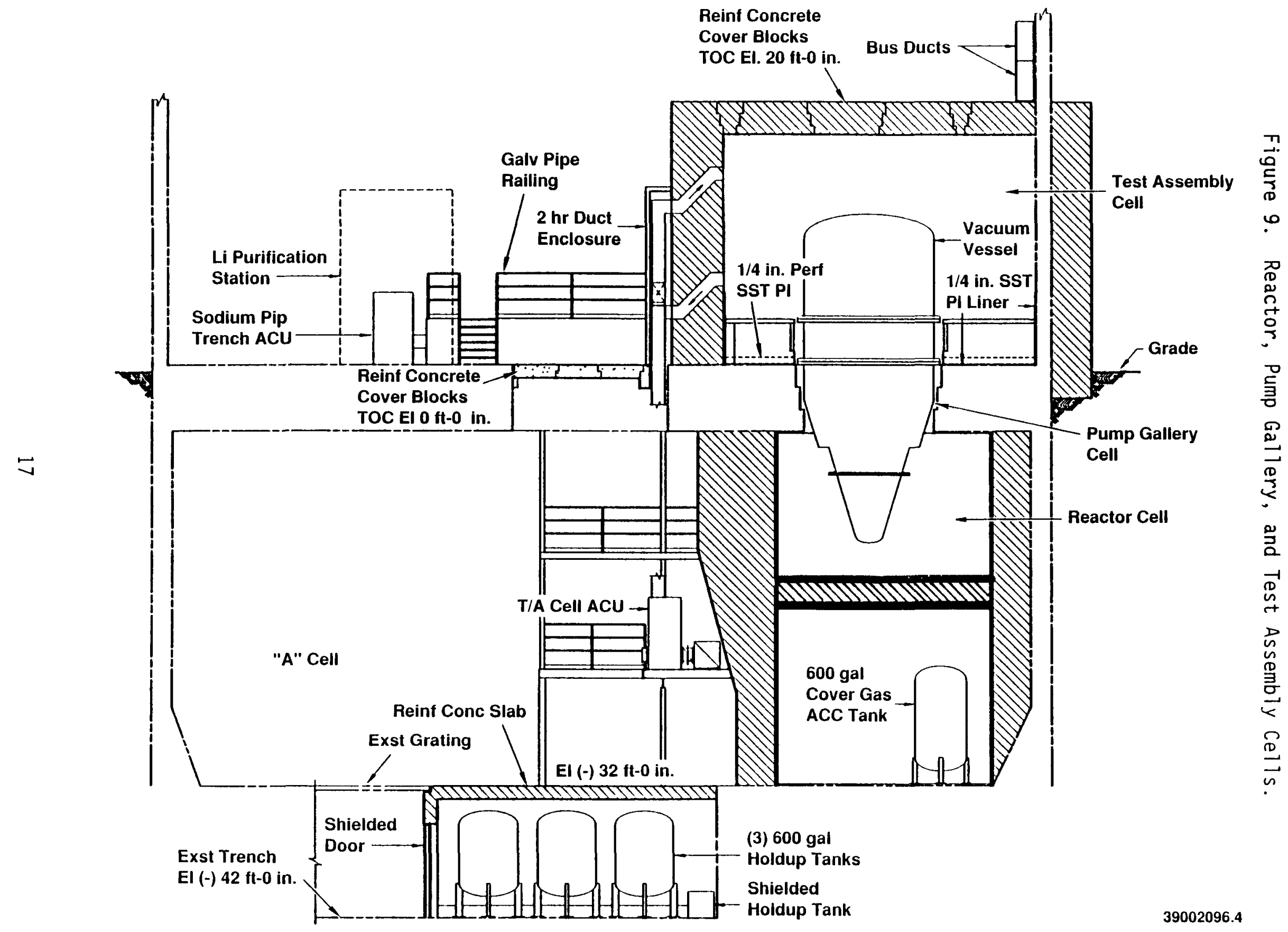


pressure. (The inerting gas is supplied to the cell as required to maintain this positive pressure.) The cells are maintained at a positive pressure to ensure that the oxygen concentration in the cells is below limits specified to protect the reactor structural material (Nb-1Zr alloy) in the event of a leak into the vacuum vessel. At high temperatures, the $\mathrm{Nb}-1 \mathrm{Zr}$ alloy reacts rapidly with oxygen causing damage to the reactor. However, if inleakage of oxygen were to occur, a backup feed-and-bleed system has been provided to limit the oxygen concentration in the cells. If the cell oxygen concentration approaches the specified limits, the inert gas will be pumped from the cell or cells at a total rate of $5 \mathrm{ft}^{3} / \mathrm{min}$. The inert gas flows through a holdup tank and is exhausted out the stack. The hold-up tank will ensure that any radioactive components have decayed to an acceptable level. A radiation monitor at the inlet to the stack will ensure that release limits are not exceeded.

\subsection{EMISSIONS RELEASE RATES}

The emissions of gaseous radionuclides from the SP-100 facility are anticipated to be activation products formed as described in Sections 6.1, 6.2 , and 6.3. Those activation products will be argon-41 ( ${ }^{41} \mathrm{Ar}$ ), carbon-14 $\left({ }^{4} \mathrm{C}\right)$, and tritium $\left({ }^{3} \mathrm{H}\right)$. No particulate emissions are expected.

NOTE: Though 365 days of operation is used in the following calculations, the reactor is not expected to operate continuously for a year (Section 4.0).

\section{Tritium:}

The emission rate for gaseous tritium was set equal to estimates of the total amount of tritium to be produced within the reactor system. The total amount of tritium estimated to be produced during one year of reactor operation is $522 \mathrm{Ci}$, which is within release guidelines. That tritium production rate was estimated as follows.

- The quantity (grams) of tritium produced by the neutron activation of the 1ithium coolant was calculated using the ORIGEN II Code (Croff 1985) for a range of full-power operations between one day and $2 \mathrm{yr}$. It is projected one full-power day will produce $1.52 \times 10^{-4} \mathrm{~g}^{3} \mathrm{H} /$ days.

- Grams of tritium produced were then converted to curies using the following formula (Bureau 1970):

$$
\operatorname{SpA}=\lambda N=(\ln 2) \mathrm{N} / \mathrm{T}_{1 / 2}
$$

Yielding $9413.5 \mathrm{Ci} / \mathrm{gram}$ of ${ }^{3} \mathrm{H}$ 
where:

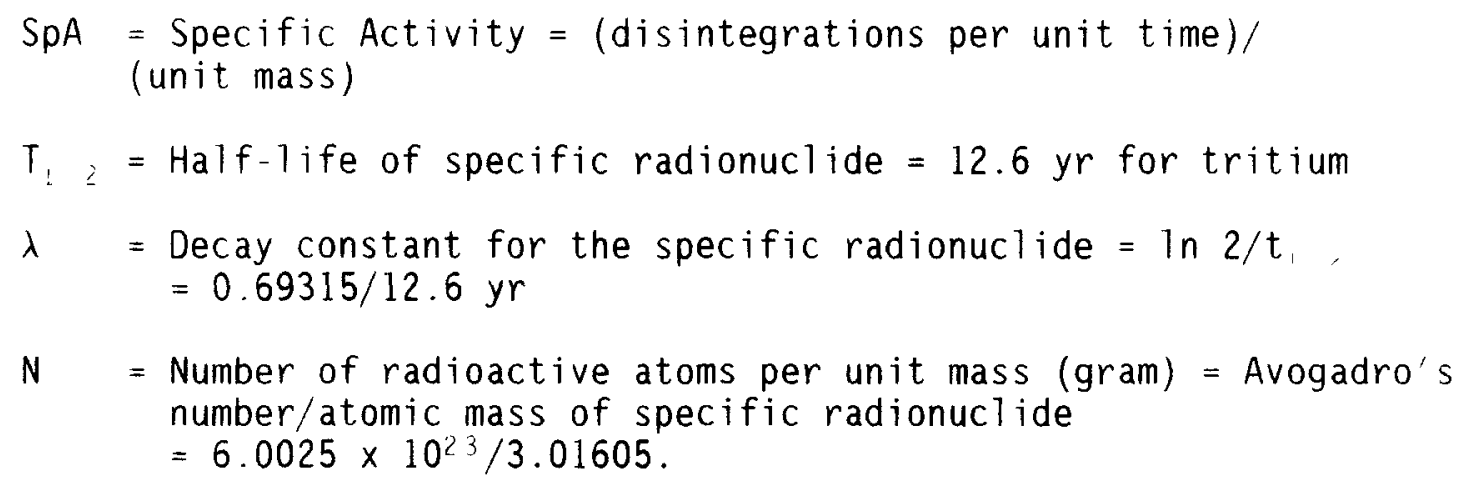

Converting curies of ${ }^{3} \mathrm{H} / \mathrm{g}$ of ${ }^{3} \mathrm{H}$ to curies of ${ }^{3} \mathrm{H} / \mathrm{d}$ :

$$
\left(9413.5 \mathrm{Ci} / \mathrm{g}^{3} \mathrm{H}\right)\left(1.52 \times 10^{-4} \mathrm{~g}^{3} \mathrm{H} / \mathrm{d}\right)=1.4 \mathrm{Ci} \mathrm{H} / \mathrm{d}
$$

Converting curies of ${ }^{3} \mathrm{H} / \mathrm{d}$ to curies of ${ }^{3} \mathrm{H} / \mathrm{yr}$ :

$$
(1.4 \mathrm{Ci} j \mathrm{H} / \mathrm{d})(365 \mathrm{~d})=522 \mathrm{Ci} / \mathrm{yr}=\text { Source Term } .
$$

\section{Argon-41:}

The emission rate of gaseous argon will be kept at or below the Derived Concentration Guide (DCG) of $1.0 \times 10^{-8} \mathrm{uC} / \mathrm{mL}$ of air (see Appendix A for a discussion of the $D C G$ ). This precipitates the release of approximately $0.75 \mathrm{Ci} / \mathrm{yr}$, as shown below:

- Release to be kept at DCG of $1.0 \times 10^{-8} \mathrm{uCi} / \mathrm{mL}$

- Stack flow rate $=5,000 \mathrm{ft}^{2} / \mathrm{min}$

- $1 \mathrm{~L}=0.0353 \mathrm{ft}^{3}$

$5,000 \mathrm{ft}: / \mathrm{min}=1.42 \times 10^{5} \mathrm{~L} / \mathrm{min}=1.42 \times 10^{8} \mathrm{~mL} / \mathrm{min}$

- $\left(1.0 \times 10^{8} u C \mathrm{i} / \mathrm{mL}\right)\left(1.42 \times 10^{8} \mathrm{~mL} / \mathrm{min}\right)(1440 \mathrm{~min} / \mathrm{d})$

$=2.0 \times 10^{i} \mathrm{uC} \mathrm{i} / \mathrm{d}$

- $\left(2.0 \times 10^{r} \mathrm{uCi} / \mathrm{d}\right)(365 \mathrm{~d})=7.5 \times 10^{5} \mathrm{uCi} / \mathrm{yr}$ $=7.5 \times 10^{-1} \mathrm{Ci} / \mathrm{yr}=$ Source Term 


\section{Carbon-14:}

The reactor test cell will be a nitrogen-filled gas space surrounding the reactor core and the lower portion of the vacuum and guard vessel. Neutrons that escape the core and reflectors will interact with the nitrogen gas in the reactor cell through a neutron/proton reaction $(n, p)$, producing ${ }^{14} \mathrm{C}$.

The annual ${ }^{14} \mathrm{C}$ production rate of $1.7 \mathrm{C}$ was $\mathrm{calculated}$ based on the following assumptions:

- Free volume of $1,000 \mathrm{ft}^{3}$ in the reactor assembly cavity

- No additional shielding surrounding the guard vessel or in the cell.

The average neutron flux $(\phi)$ for the ${ }^{14} \mathrm{~N}(n, p){ }^{14} \mathrm{C}$ reaction in the reactor vault with no near-reactor shield was determined using the modeling code MCNP (Briesmeister 1986) and found to be $9.28 \times 10^{10}\left(\mathrm{n} \mathrm{b} / \mathrm{cm}^{c} \mathrm{~s}\right)$. The atom density for nitrogen at standard temperature and pressure is $5.38 \times 10^{--}$ (atoms $/ \mathrm{b}-\mathrm{cm}$ ). This gives a $\phi \sigma \mathrm{N}_{0}$ of $4.99 \times 10^{6}$ (atoms $/ \mathrm{cm}^{3}-\mathrm{s}$ ) The activation level of the gas leaking out of the reactor cell is given by:

$$
A=\left[\left(\phi \sigma N_{0}\right)(\lambda)\left(1-e^{-(\lambda+F / V) t}\right)\right] /(\lambda+F / V)
$$

where:

$$
\begin{array}{rlrl}
A= & \begin{array}{l}
\text { Activation level of gas } \\
\text { flowing out of reactor cell. }
\end{array} & & \begin{array}{l}
\left(\mathrm{uCi} / \mathrm{cm}^{3}\right)(\mathrm{n}) \\
\text { conversion fro }
\end{array} \\
\phi= & \text { Neutron flux in cell } & & \left(\mathrm{n} / \mathrm{cm}^{2}-\mathrm{s}\right) \\
\sigma= & \text { Cross section } & & (\mathrm{b}) \\
& 4 \mathrm{~N}(\mathrm{n}, \mathrm{p})^{14} \mathrm{C} \text { in this case } & & \\
\mathrm{N}_{0}= & \text { Atom density of target atoms in } & & (\text { atoms } / \mathrm{b}-\mathrm{cm}) \\
& \text { the reactor cell } & & \\
\lambda= & \text { Decay constant, } & & \\
& \text { for } 4 \text { C in this case } & & \left(\mathrm{s}^{-1}\right) \\
\mathrm{F}= & \text { Leak rate from reactor cell } & & \left(\mathrm{cm}^{3} / \mathrm{s}\right) \\
V= & \text { Rreactor cell volume } & \left(\mathrm{cm}^{3}\right) \\
t= & \text { Time since start of reactor } & (\mathrm{s}) \\
& \text { operation. }
\end{array}
$$

Constant values used were:

$$
b=\text { Barn }=1.0 \times 10^{24} \mathrm{~cm}^{c}
$$

$\left(\mathrm{uCi} / \mathrm{cm}^{3}\right)$ (note: requires conversion from [dis/s-cm $\left.\mathrm{Cm}^{3}\right]$ ) 


$$
\begin{aligned}
\phi \sigma & =9.28 \times 10^{10}\left([\mathrm{n}-\mathrm{b}] /\left[\mathrm{cm}^{2}-\mathrm{s}\right]\right) \\
N_{0} & \left.=5.38 \times 10^{-5}([\text { atoms }] / \mathrm{b}-\mathrm{cm}]\right) \\
\lambda & =3.84 \times 10^{-12} \mathrm{~s}^{-1} \\
V & =1.005 \times 10^{8} \mathrm{~cm}^{3} \\
t & =6.30 \times 10^{7} \mathrm{~s} .
\end{aligned}
$$

Because the half 1 ife of ${ }^{14} \mathrm{C}$ is very long relative to the leakage to volume ratio $(F / V)$, the total production over the 2 yr reactor operating period is an accurate measure of potential ${ }^{14} \mathrm{C}$ emissions. The calculated total production is approximately $3.3 \mathrm{Ci}$ over $2 \mathrm{yr}$.

Assuming a uniform annual release of $1.7 \mathrm{Ci}$ of $1^{4} \mathrm{C}$, the stack release concentration would be $2.0 \times 10^{-8} \mathrm{uCi} / \mathrm{ml}$, which is well below the $D C G$ (Appendix B) of $5.0 \times 10^{-7} \mathrm{uCi} / \mathrm{ml}$.

Table 1 presents the controlled emission rates for ${ }^{41} \mathrm{Ar},{ }^{3} \mathrm{H}$, and ${ }^{14} \mathrm{C}$.

Table 1. Controlled Emission Rates of Tritium, Argon, and Carbon.

\begin{tabular}{ccc}
\hline Radionuclide & Emission Rate* & $(\mathrm{Ci} / \mathrm{yr})$ \\
\hline${ }^{3} \mathrm{H}$ & 522 \\
${ }^{1} \mathrm{Ar}$ & 0.75 \\
${ }^{14} \mathrm{C}$ & 1.7 \\
\hline
\end{tabular}

*These releases are based on the extremely conservative assumption that the reactor will operate 365 days per year (Section 4.0).

\subsection{OFFSITE DOSES}

The AIRDOS-EPA (Clean Air Act Code) computer code was used to calculate the dose from the SP-100 GES to the maximally exposed offsite individual and thus demonstrate compliance with 40 CFR 61, Subpart $H$, and WAC 402-80-050.

Meteorological data input to the AIRDOSE-EPA code include mixing height, rainfall rate, average air temperature, vertical temperature gradient, wind direction frequency, wind speed, and atmospheric stability. This information was obtained from the database compiled by the Hanford Meteorological Station (HMS). The HMS data on airspeed, direction, and temperature are collected at a $70-\mathrm{m}(200-\mathrm{ft})$ tower located on the Hanford Site near the southwest corner of the 300 Area. Wind speed and direction are based on hourly data collected at the 300-Area meteorological tower 10-m (33-ft) level during the years 1983 to 1987. Atmospheric stability was estimated from the temperature 
gradient between the $9.1-\mathrm{m}(30-\mathrm{ft})$ and $70-\mathrm{m}(200-\mathrm{ft})$ levels at the tower for the same period using standard methods of the U.S. Nuclear Regulatory Commission. Air temperature and mixing height are also 5-yr averages of hourly data. Temperature is measured at the tower $70-\mathrm{m}(200-\mathrm{ft})$ level, and mixing height data are collected by onsite acoustic sounders.

Joint frequency data, as reported by the HMS, are modified for input into AIRDOSE-EPA by conversion to true average and reciprocal average wind speeds for each direction and stability class. The meteorological data are then used to calculate $X / Q$ values for each radionuclide, which are also a function of radiological half-life and dry deposition velocity. For purposes of this calculation, deposition velocities are assigned as follows: $1.0 \times 10^{-3} \mathrm{~m} / \mathrm{s}$ for all particulate materials, $1.0 \times 10^{-2} \mathrm{~m} / \mathrm{s}$ for iodine isotopes, and 0 for all gases.

Source Terms: Projected annual releases from SP-100 as presented in Table 2.

Release Height: The SP-100 stack height is $30.5 \mathrm{~m}(100 \mathrm{ft})$.

Inhalation Rate: $8,500 \mathrm{~m}^{3} / \mathrm{yr}$.

Maximally Exposed Individual: Doses were estimated for an individual living $5.6 \mathrm{~km}$ (3.5 mi) south of the 309 Building.

Meteorology: Hanford Meteorological Station data and onsite meteorological data, as discussed above.

\subsubsection{Results}

Table 2 shows that the projected doses from SP-100 controlled airborne radiological emissions to the maximally exposed offsite individual are 0.06 mrem to the whole body, and .07 mrem to the critical organ. The whole body dose attributable to radiological emissions from SP-100 will, then, constitute $0.6 \%$ of the 40 CFR 61.92 Effective Dose Equivalent regulatory 1 imit of 10 mrem to the maximally exposed offsite individual, and only $0.2 \%$ of the WAC 402-80-050 regulatory 1 imit.

The natural background radiation dose for the Tri-Cities area of Washington State is estimated to be $300 \mathrm{mrem}$ (Jaquish 1989). The projected dose from the SP-100 would constitute $0.02 \%$ of natural ambient radiation. 
Table 2. Offsite Dose Estimates for an Individual

Receiving Maximum Exposure to Airborne Radiological Emissions From SP-100 (mrem/yr).

\begin{tabular}{ccc}
\hline Radionuclide & Whole body & $\begin{array}{c}\text { Critical organ } \\
\text { (thyroid) }\end{array}$ \\
\hline${ }^{14} \mathrm{C}$ & $1.8 \mathrm{E}-02$ & $2.1 \mathrm{E}-02$ \\
${ }^{3} \mathrm{H}$ & $3.1 \mathrm{E}-02$ & $3.0 \mathrm{E}-02$ \\
${ }^{41} \mathrm{Ar}$ & $2.8 \mathrm{E}-05$ & $3.5 \mathrm{E}-05$ \\
\hline Total & $4.9 \mathrm{E}-02$ & $5.1 \mathrm{E}-02$ \\
\hline
\end{tabular}

\subsection{REFERENCES}

Briesmeister, J. F., Editor, MCNP - A General Monte Carlo Code for Neutron and Photon Transport, Version 3a, LA-7396-M, Rev. 2, Los Alamos National Laboratory, Los Alamos, New Mexico, 1986. (Revision of this manual for version $3 B$ has also been distributed.)

Bureau of Radiological Health and the Training Institute Environmental Control Administration, 1970, Radiological Health Handbook (Revised Edition) U.S. Department of Health, Education, and Welfare, Rockville, Maryland.

Croff, A. G., 1985 (update of 1984 document), ORIGEN II, Isotope Generation and Depletion Code (Matrix Exponential Method), CCC 371 , Oak Ridge National Laboratory, Oak Ridge, Tennessee.

Dunning, D. E., R. W. Leggett, M. G. Yalcintas, 1988 (update of 1980 document), RSIC Computer Code Collection RADRISK, Estimates of Radiation Doses and Health Effects from Inhalation or Ingestion of Radionuclides CCC-422, Oak Ridge National Laboratory, Oak Ridge, Tennessee.

EPA, 1984, Background Information Document (Integrated Risk Assessment), Final Rules Radionuclides Vo1. 1, EPA 520/1-022-1, U.S. Environmental Protection Agency, Washington, D.C.

EPA, 1989, National Emission Standards for Hazardous Air Pollutants; Radionuclides; Final Rule and Notice of Reconsideration, U.S. Environmental Protection Agency, Washington, D.C.

Jaquish, R. E., 1989, Hanford Site Environmental Report for Calendar Year 1988, prepared for the U.S. Department of Energy by Pacific Northwest Laboratory under Contract DE-AC06-76RLO 1830.

Oak Ridge National Laboratory, 1987, RSIC Computer Code Collection, CAAC, Code System for Implementation of Atmospheric Dispersion Assessment Required by the Clean Air Act, CCC-476, Oak Ridge National Laboratory, Oak Ridge, Tennessee. 
DOE/RL-90-15

APPENDIX A

DERIVED CONCENTRATION GUIDE (DCG)

A-1 


\section{APPENDIX A}

\section{DERIVED CONCENTRATION GUIDE (DCG)}

The DCG values are derived for the purpose of relating concentration of radionuclides in the environment to a human dose. When a standard man is exposed continuously for $1 \mathrm{yr}$ to air concentrations at one times the DCG value, he will receive an effective committed dose equivalent of $100 \mathrm{mrem}$ to the whole body or other limiting dose to an organ. When more than one radionuclide is involved in the exposure, the fractional relationship of the concentration of each radionuclide to its respective DCG value must be summed to determine the total dose from the radionuclide mix. The DCG values relate to a $100-$ mrem dose only when applied at the point of exposure to humans. For the SP-100 facility, these values are specified at the release point for exhaust from containment (stack). The chronic dose to a resident is lower because of meteorological dispersion.

The DCGs for the critical radionuclides to be emitted by the SP-100 GES are as follows:

$\begin{array}{cc}\text { Radionuclide } & \text { DCG } \\ { }^{41} \mathrm{Ar} & 1.0 \mathrm{E}-08 \mathrm{uCi} / \mathrm{m} 1 \text { of air } \\ { }^{14} \mathrm{C} & 5.0 \mathrm{E}-07 \mathrm{uCi} / \mathrm{ml} \text { of air } \\ { }^{3} \mathrm{H} & 1.0 \mathrm{E}-07 \mathrm{uCi} / \mathrm{ml} \text { of air }\end{array}$


DOE/RL-90-15

\section{DISTRIBUTION}

Number of copies

ONSITE

31

Westinghouse Hanford Company

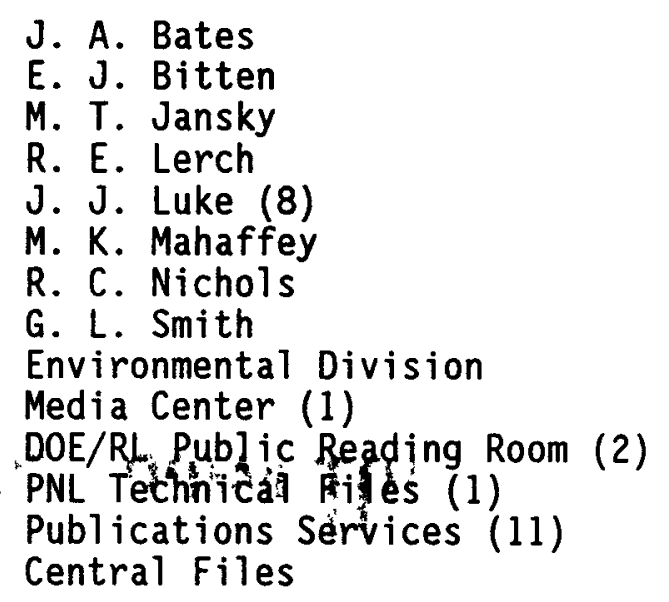

H4-50

L4-76

H4 -57

B2-35

H4 -57

L4-73

B3-02

L4- 75

H4 - 22

A1-65

$\mathrm{K} 1-11$

A2- 24

L8-04

"NAT NOT MAI:ROFII!". 
DOE/RL-90-15

This page intentionally left blank.

(.)

Distr-2 